\title{
EFFECT OF FAMILY SUPPORT ON CHILD GROWTH AND DEVELOPMENT IN SUKOHARJO, CENTRAL JAVA
}

\author{
Fitria Hayu Palupi'), Ana Wigunantiningsih'), Luluk Nur

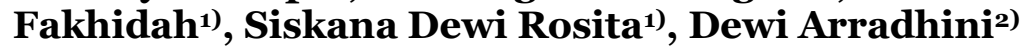 \\ 1)Midwifery Study Program, School of Health Science Mitra Husada Karanganyar \\ ${ }^{2}$ Nursing Bachelor Program, School of Health Science Mitra Husada Karanganyar
}

\begin{abstract}
Background: Impaired growth and development of children remains a serious problem globally. The role of the family, especially the support and participation of parents are the important factors in monitoring the growth and development of infants/ toddlers. This study aimed to determine the effect of family support on the growth and development of infants/ toddlers.

Subjects and Method: This was a cross-sectional study conducted at Kragilan Village, Mojolaban, Sukoharjo, Central Java in November 2018. The study subjects were total of 115 mothers with children aged 1-60 month. Multistage cluster sampling technique was conducted. Dependent variable was growth and development of children. Independent variable was family support. The data for family support was collected by questionnaire. The data for growth of infants/ toddlers was collected by assessing growth chart (monitoring whether weight gain or loss from previous month), assessing length/height-for-age (normal height or stunted), head circumference measurement (macrocephalic/ microcephalic/ normocephalic), and assessing teething chart (erupts/ loss of teeth in accordance with age or not). The data for development of infants/ toddlers was collected by evaluating the gross motor, fine motor, language, and social skills based on child development pre-screening questionnaire.

Results: Good family support increases growth $(b=0.895 ; \mathrm{p}<0.001)$ and development $(b=$ $0.337 ; \mathrm{p}<0.001$ ) of infants/ toddlers.

Conclusion: Good family support increases growth and development of infants/ toddlers.
\end{abstract}

Keywords: family support, growth, development

Correspondence:

Fitria Hayu Palupi. Midwifery Study Program, School of Health Science Mitra Husada Karanganyar. Jl. Brigjen Katamso Barat, Papahan, Tasikmadu, Karanganyar, Central Java, Indonesia. Email: fitriahp45@gmail.com. Mobile: +62853268480o8.

The $7^{\text {th }}$ International Conference on Public Health

Solo, Indonesia, November 18-19, 2020 | 233 https://doi.org/10.26911/the7thicph.03.53 